\title{
Nilgirianthus ciliatus mediated environment friendly extracellular synthesis of AgNps to exact its potential against Dengue vector, Aedes aegypti and Staphylococcus aureus
}

\author{
K. Meenambigai, R. Kokila, A. Naresh Kumar \\ Department of Zoology, School of Life Sciences, Periyar University, Salem, Tamil Nadu, India
}

\begin{abstract}
Aedes aegypti, the dengue vector, is a menace continuing since 1780; it is due to development of resistant to synthetic insecticides and Staphylococcus aureus, the common microbial pathogen agent of food poisoning, skin infections and respiratory infections have developed multidrug resistant, which forced us to focus on novel agent for which the dengue vector and bacterial pathogen have not practiced to develop resistant and which cannot detoxify it using its usual enzyme activity as it did earlier. Silver nanopar-
\end{abstract}

Correspondence: Arjunan Naresh Kumar, Department of Zoology, School of Life Sciences, Periyar University, Salem - 636011, Tamil Nadu, India.

Tel.: +91.427.2345766, Ext. 328

E-mail: nareshphd@gmail.com

Key words: Nilgirianthus ciliatus, Silver nanoparticles, Aedes aegypti, Staphylococcus aureus, Biosynthesis, Insecticidal activity, Antibacterial activity.

Acknowledgements and Funding: We sincerely acknowledge and thank Periyar University, Salem, Tamil Nadu for providing all required laboratory facilities in relation to this research work. We also thank University Grants Commission (UGC), New Delhi, India for the award of Rajiv Gandhi National Fellowship with financial support (Ref No: F1-17.1/ 2015-16/ RGNF2015-17-SC-TAM-10313) to carry out this research work.

Contributions: the authors contributed equally.

Conflict of interest: the authors declare no potential conflict of interest.

Received for publication: 28 March 2018.

Revision received: 9 June 2018.

Accepted for publication: 9 June 2018.

CC Copyright K. Meenambigai et al., 2018

Licensee PAGEPress, Italy

Journal of Entomological and Acarological Research 2018; 50:7450

doi:10.4081/jear.2018.7450

This article is distributed under the terms of the Creative Commons Attribution Noncommercial License (by-nc 4.0) which permits any noncommercial use, distribution, and reproduction in any medium, provided the original author(s) and source are credited. ticles a challenging insecticidal agents for the toxic degrading enzymes of both the insect and microbe was the target of our present study to excavate the potential in killing immature of dengue vector and bacterial pathogen. Green protocolled nanoparticles were successfully synthesized using leaf extract of Nilgirianthus ciliatus which act as reducing as well as capping agents. The UVvis spectra observed at $441 \mathrm{~nm}$ confirmed the presence of silver nanoparticles. XRD and FT-IR confirmed the crystalline nature and organic capping around the silver nanoparticles respectively. SEM and DLS showed the average size at $117 \mathrm{~nm}$ and the particle dispersion was at $-17.2 \mathrm{mV}$ zeta potential.

\section{Introduction}

Mosquitoes take the lead in causing human diseases and killing humans and other animals around the world, due to their ability to carrying pathogens from individual to individual. Millions of lives are lost and still being victims for her hunger (Benelli et al., 2017; Santhosh et al., 2015). Dengue and chikungunya killer arbovirus diseases transmitted by the adult female Aedes aegypti which are highly adaptable to biotic stimuli (Prado et al., 2017).The pathogen travel from human to human is mediated by Aedes aegypti (L.) as the primary vector ( $\mathrm{Li}$ et al., 2012).This species is also a vector of few other diseases in human like yellow fever, Zika fever and Mayaro virus disease (Suganya et al., 2017). This species is a serious vector of infectious diseases threatening around 2.5 billion people around the globe

(Hafeez et al., 2017). Aedes aegypti mediated infections affected 50-100 million cases every year worldwide with atleast half million victims have lost their lives with a five year period from 2010 to 2015 (Singla et al., 2016).

Management of this vector was failed since many generations due to human activity (providing breeding sites), population (providing maximum hosts), environmental factors (providing optimum condition for growth \& development), resistant development (capable for detoxifying target insecticides) and many other (Ghosh et al., 2012). DDT, dieldrin, organophosphrous, fenithothion and propoxurare the insecticides used in India to control the vector mosquito, whereas, in very few generations they started metabolizing these foreign agents (Vasantha et al., 2016). Moreover, these mosquito control agents remind back as pollutant causing side effects and started reducing the non-target populations leading to an ecological imbalance (Mathew et al., 2015). Further bioaccumulation of these synthetic insecticides in aquatic 
human feeds had few impacts on human health and other animals as well (Strode et al., 2012; Gambarra et al., 2013; Garcez et al., 2013; Pereira et al., 2014).

Staphylococcu aureus a widespread bacterial food-poisoning pathogen common in dairy industries worldwide (Zecconi et al., 2006; Persson et al., 2011). It also leads to pneumonia, bacteraemia, wound infections, surgical site infections and sepsis (Adibhesami et al., 2017). Nasopharyngeal colonization of Staphylococcus aureus was detected in $7.38 \%$ children (Chande et al., 2009). This bacterial pathogen is also a cause of respiratory, skin and tissue disease and infection in vascular grafts (Edwards et al., 2012; Shak et al., 2013). Problem with treating Staphylococcus aureus infections is development of resistance in it to all available antibiotics as well as to the evolving new antibiotics (Ha \& Fowler, 2013). Indeed, Methicillin Resistant Staphylococcus aureus (MRSA) strains have long been a problem in hospital and community setting worldwide (Cuny et al., 2010)

In order to overcome the problem nanotechnology will be a best alternative. Development in novel instrumentations and reliable techniques progression of nanotechnology is being very fast leading to novel therapeutic interventions (Hamed et al., 2017). At present nanotechnology left no field behind becoming a promising research domain with broad range of application including antibacterial drugs and vector control programs (Muthukumaran et al., 2015).Eco-friendly approach for the synthesis of nanoparticles replacing synthetic chemicals as reducing and capping agents will use less energy, less or non-toxic for handling, no bioaccumulation and much effective as it targets the intracellular components (Kumar et al., 2017). Moreover, the organic capping of metal nanoparticles from the natural reducers reduces the toxicity of metal nanoparticles (Priya et al., 2016).

Bacteria, fungi and plant products are the important bio reducing agents in synthesis of nanoparticles. The active secondary metabolites play a major role in reduction and capping of metal ions forming nanoparticles (Nareshkumar et al., 2013).In the present study, Nilgirianthus ciliatus a shrub in Acanthaceae family with high potential medicinal compounds was used as a bioreductant in synthesis of silver nanoparticles.

Nilgirianthus ciliatus is an aromatic slender shrub of Western Ghats with extensive applications in Ayurveda and used in traditional culture to treat various diseases (Rameshkumar et al., 2015; Rani et al., 2013). Aquatic and solvent extracts of this plant also posses antibacterial and antifungal activities (Neethu et al., 2014). Terpenoids, flavonoids, phytosterols, phenolic compounds, fixed oils and carbohydrates were reported in this plants which has the capability to reduce the Ag ions and cap them to form a stable nanomaterial (Maria \& Krishnan, 2016). This green synthesis provides an economic, eco-friendly and clean synthesis route to $\mathrm{Ag}$ nanoparticles.

\section{Materials and Methods}

\section{Collection and preparation of leaves broth}

Nilgirianthus ciliatus leaves were collected from ABS Garden, Kariyapatty, Salem, Tamil Nadu, India. The leaves were washed with tap water, shade dried in laboratory with a regular environmental condition. The shade dried leaves were powdered and further dried for 5 days at room temperature. Broth solution was prepared by taking $5 \mathrm{~g}$ of the dried powder in a $300 \mathrm{~mL}$ Erlenmeyer flask with $100 \mathrm{~mL}$ of sterile distilled water and then boiling the mixture for $5 \mathrm{~min}$ before finally decanting it. They were stored at $4^{\circ} \mathrm{C}$ and used within a week.

\section{Synthesis of silver nanoparticles}

$10 \mathrm{~mL}$ of Nilgirianthus ciliatus leaves broth was added to 190 $\mathrm{mL}$ of $6 \mathrm{mM}$ aqueous $\mathrm{AgNO}_{3}$ solution for reduction of $\mathrm{Ag}^{+}$ions. The synthesis rate and particle size of the silver nanoparticles was studied by carrying out the reactions in water bath at $90^{\circ} \mathrm{C}$ with reflux at a gradual increasing reaction time. The silver nanoparticle solution thus obtained at $120 \mathrm{~min}$ (maximum absorption at around $440 \mathrm{~nm}$ ) was purified by repeated centrifugation at $8000 \mathrm{rpm}$ for $20 \mathrm{~min}$ followed by redispersion of the pellet in deionized water.

\section{Characterization of silver nanoparticles}

UV-vis spectra were recorded as a function of reaction time on a UV-1800 Shimadzu spectrophotometer operated at resolution of 1 $\mathrm{nm}$. After freeze drying of the purified silver particles, the structure and composition were analyzed by $10 \mathrm{kV}$ Ultra High Resolution Scanning Electron Microscope (FEI QUANTA - 200 SEM) spectroscopy. The surface groups of the nanoparticles were qualitatively confirmed using FTIR spectroscopy (Perkin-Elmer spectrum 2000 FTIR spectrophotometer). X-ray diffraction using Cuk $\alpha$ radiation (PANanlytical X'pert Pro MPD diffractometer) was used to determine the crystalline structure of silver nanoparticles. The Particles size distribution of silver nanoparticles was evaluated using dynamic light scattering (DLS) measurement conducted with a Malvem Zetasizer Nano series compact Scattering Spectrometer. Data obtained were analyzed using Zetasizer software.

\section{Mosquito culture}

The eggs of Aedes aegypti were collected from water stored containers of local residential area in Salem, Tamil Nadu, India. These were returned to the laboratory and transferred (in approximately the same aliquot numbers of eggs) to $18 \mathrm{~cm} \mathrm{~L} \times 13 \mathrm{~cm} \mathrm{~W}$ $\times 4 \mathrm{~cm} \mathrm{D}$ enamel trays containing $500 \mathrm{~mL}$ of water where they were allowed to hatch.

Mosquito larvae were reared at $29 \pm 2^{\circ} \mathrm{C}$ and $75-85 \% \mathrm{RH}$ in a 14:10 (L:D) photoperiod. Larvae were fed $5 \mathrm{~g}$ ground dog biscuit and brewer's yeast daily in a 3:1 ratio. Pupae were collected and transferred to plastic containers with $500 \mathrm{ml}$ of water. The container was placed inside a screened cage $(90 \mathrm{~cm} \mathrm{~L} \times 90 \mathrm{~cm} \mathrm{H} \times 90 \mathrm{~W})$ to retain emerging adults, for which $10 \%$ sucrose in water solution (v/v) was available adlibitum. On day 5 post emergence, the mosquitoes were provided access to a rabbit host for blood feeding. The shaved dorsal side of the rabbit was positioned on the top of the mosquito cage in contact with the cage screen (using a cloth sling to hold the rabbit) and held in this position overnight. Glass Petri dishes lined with filter paper and containing $50 \mathrm{~mL}$ of water were subsequently placed inside the cage for oviposition by female mosquitoes.

\section{Larval toxicity test}

Laboratory colonies of F3 mosquito larvae were used for larvicidal activity. The AgNps nanoparticle was evaluated at 1, 5, and $10 \mathrm{mg} / \mathrm{L}$ concentrations and untreated distilled water served as control. Twenty five actively swimming Aedes aegypti immature at different developmental stages were sieved out from the rearing trays to $250 \mathrm{ml}$ capacity experimental plastic containers containing $100 \mathrm{ml}$ distilled water with selected concentrations of Silver nanoparticle and untreated control setup in triplicate (WHO, 2005). The larvae were fed adlabitum on fine powdered liver and glucose at a ratio of 3:2 (wt: wt) as enhanced method of (Roberts, 1998) and as described by (Nareshkumar et al., 2013) and the larval mortality was assessed after $24 \mathrm{~h}$ and $48 \mathrm{~h}$ of exposure by probing the larvae with needle and moribund larvae were counted as dead (Azmi et al., 1998). The control mortalities were corrected by using Abbott formula (1925): 
Corrected mortality $=$

Observed mortality in treatment - observed mortality in control $\times 100$ 100 - Control mortality

Percentage mortality $=$ Number of dead larvae $\times 100$ Number of larvae introduced

\section{Anti-bacterial activity}

The antibacterial activity of AgNPs against Staphylococcus aureus was experimented by the standard disc diffusion method (Diao et al., 2013). The Gram positive bacteria Staphylococcus aureus (MTCC 96), procured from Department of Microbiology, Periyar University, Salem, India was cultured using Agar agar type I (AA) and Nutrient Broth (NB). Filter paper discs $(6 \mathrm{~mm})$ were impregnated at concentrations from $25 \mu \mathrm{L}$ to $100 \mu \mathrm{L}$ AgNPs/disc. The AgNP impregnated filter paper discs were placed on the Staphylococcus aureus culture plates incubated overnight at $37^{\circ} \mathrm{C}$. The diameters of the zones of inhibition around each filter paper disc were then recorded. The experiments were setup in triplicate.

\section{Statistical analysis}

Probit analysis was used to evaluate the median Lethal Concentration $\left(\mathrm{LC}_{50}\right)$, and the respective $95 \%$ fiducial limits for each stage of development in immature Aedes aegypti. Mortality data subjected to immature developmental stages were analyzed using Analysis of Variance (ANOVA) methods, where the $1^{\text {st }}, 2^{\text {nd }}, 3^{\text {rd }}$ and $4^{\text {th }}$ instars larvae were dependent variables and the concentrations used were independent variables. The level of significance used in all tests was 5\%. Statistical significance of mean differences was assessed by Tukey's honestly significant difference (HSD) test. Analyses were made using SPSS Software version 16.0.

\section{Results}

\section{Ultra-violet visible absorption spectroscopy studies}

The silver nanoparticles synthesized mediated by Nilgirianthus

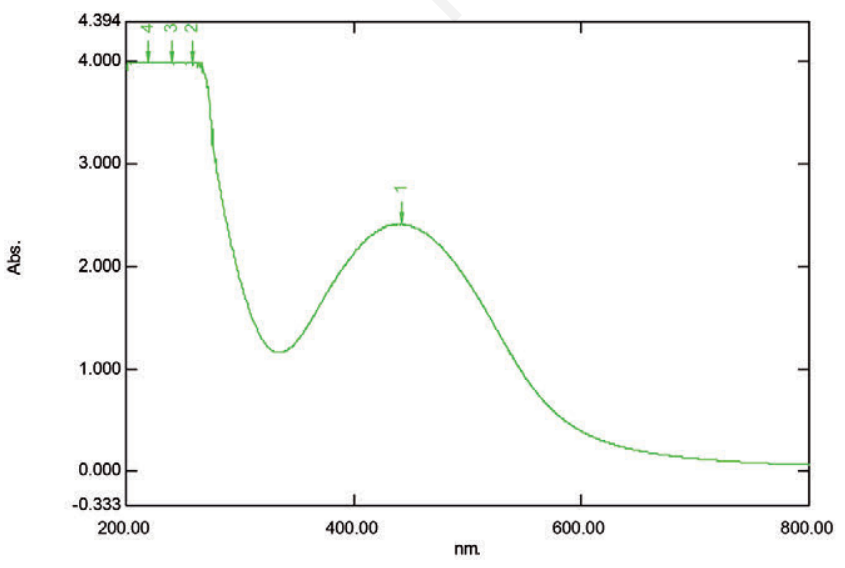

Figure 1. Ultraviolet - visible spectra recorded of silver nanoparticles synthesized using Nilgirianthus ciliatus leaf extract at 120 min reaction time. ciliatus leaf extracts were confirmed visually by change of colour from yellow to dark brown. Initially, when leaf extract added to the $\mathrm{AgNO}_{3}$ solution yellow colour appeared and turned dark brown as it was heated in a magnetic stirrer $\left(80^{\circ} \mathrm{C}\right)$ for 2 hours. The appearance of dark brown colour is considered as visual technique showing the presence of Ag NPs. For further confirmation the dark brown solution is taken to UV absorption spectroscopy and the silver nanoparticles recorded from the reaction medium at $80^{\circ} \mathrm{C}$ using $5 \%$ Nilgirianthus ciliatus leaf extract with $6 \mathrm{Mm} \mathrm{AgNO} 3$ exposures to $2 \mathrm{~h}$ of reaction time is shown in Figure 1. The Surface Plasmon Resonance band of the silver nanoparticle mediated by Nilgirianthus ciliatus leaf extracts was recorded at $441 \mathrm{~nm}$ confirmed the presence of silver nanoparticles.

\section{X-ray diffraction studies}

Silver nanoparticles analyzed by UV-vis spectrophotometer was freeze dried to come out with a powder form for verification under XRD. The diffraction of X-rays travelling through the silver nanoparticles mediated by Nilgirianthus ciliatus leaf extract was recorded as peaks at $27.9^{\circ}, 32.34^{\circ}, 38.64^{\circ}, 46.44^{\circ}, 57.44^{\circ}$ and $77.04^{\circ} 2 \theta$ corresponding to the facets $111,220,226,200,264$ and 311 of lattice planes indexed as face centered-cubic crystals of silver (Figure 2). Hence, XRD pattern confirmed that the silver nanoparticles formed here are crystalline in nature. No additional diffraction peaks were observed other than the characteristic peak of the silver structure that reflects the purity of synthesized silver nanoparticles, which is comparable with the Joint Committee on Power Diffraction Standard (JCPDS) values.

\section{Fourier transform infrared spectroscopy (FTIR) studies}

FTIR spectra of silver nanoparticles were analyzed to identify the possible bio molecules responsible for the reduction of silver nitrate to silver nanoparticles and capping of the bio reduced silver nanoparticles synthesised by Nilgirianthus ciliatus leaf extract (Figure 3). FTIR spectrum recorded major peaks positioned at $3378.78,1600.11,1383.11$ and $1098.47,600.11 \mathrm{~cm}^{-1}$. The peak recorded at $3378.78 \mathrm{~cm}^{-1}$ corresponds to the stretching vibrations of a hydroxyl $(\mathrm{O}-\mathrm{H})$ group and the spectral peak at $1600.11 \mathrm{~cm}^{-1}$ was assigned to stretching vibration $(\mathrm{C}=\mathrm{O})$ in carbonyl compounds characterized by the presence of major constituents of flavonoids

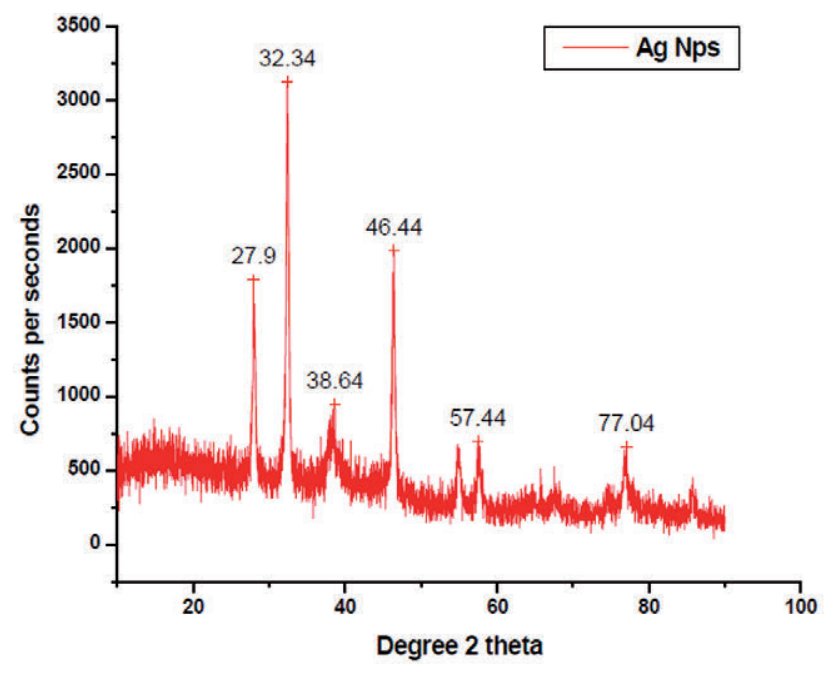

Figure 2. XRD pattern of silver nanoparticles synthesized using Nilgirianthus ciliatus. 
and terpenoids. The band formed at $1383.11 \mathrm{~cm}^{-1}$ corresponds to the bending mode of alpha $\mathrm{CH} 3$ a possible methyl group in aldehydes and ketones of Nilgirianthus ciliatus. The peak at 1098.47 $\mathrm{cm}^{-1}$ matches with the C-N stretching vibration of aliphatic amines, alcohol or phenols characterizing the presence of polyphenols. A stretching vibration band which appears at $600.11 \mathrm{~cm}^{-1}$ may be due to the adsorption or interaction of $\mathrm{O}-\mathrm{H}$ group on the surface of silver nanoparticles confirming the surface added stable silver nanoparticles.

\section{Scanning electron microscopy (SEM) studies}

SEM images enabled us to visualize the size and shape of Ag

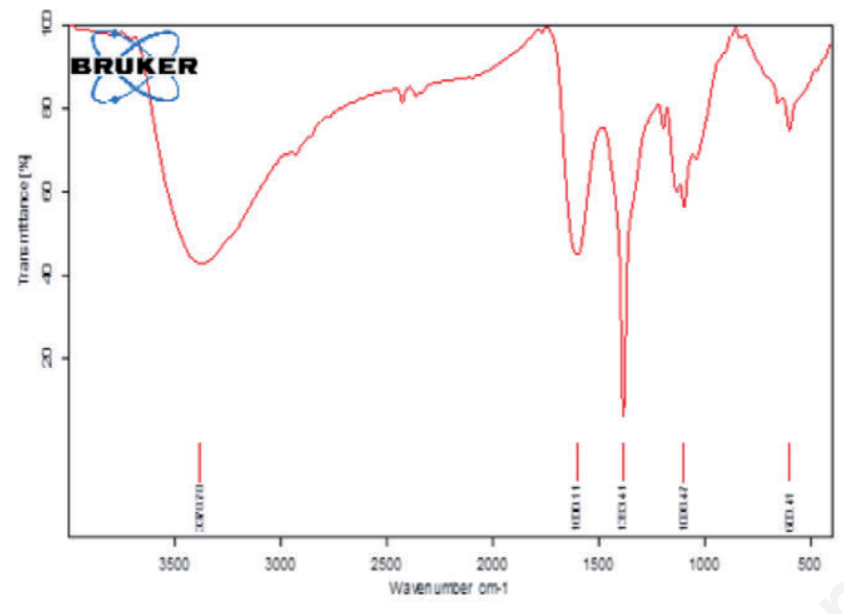

Figure 3. FT-IR pattern of silver nanoparticles synthesized using Nilgirianthus ciliatus.

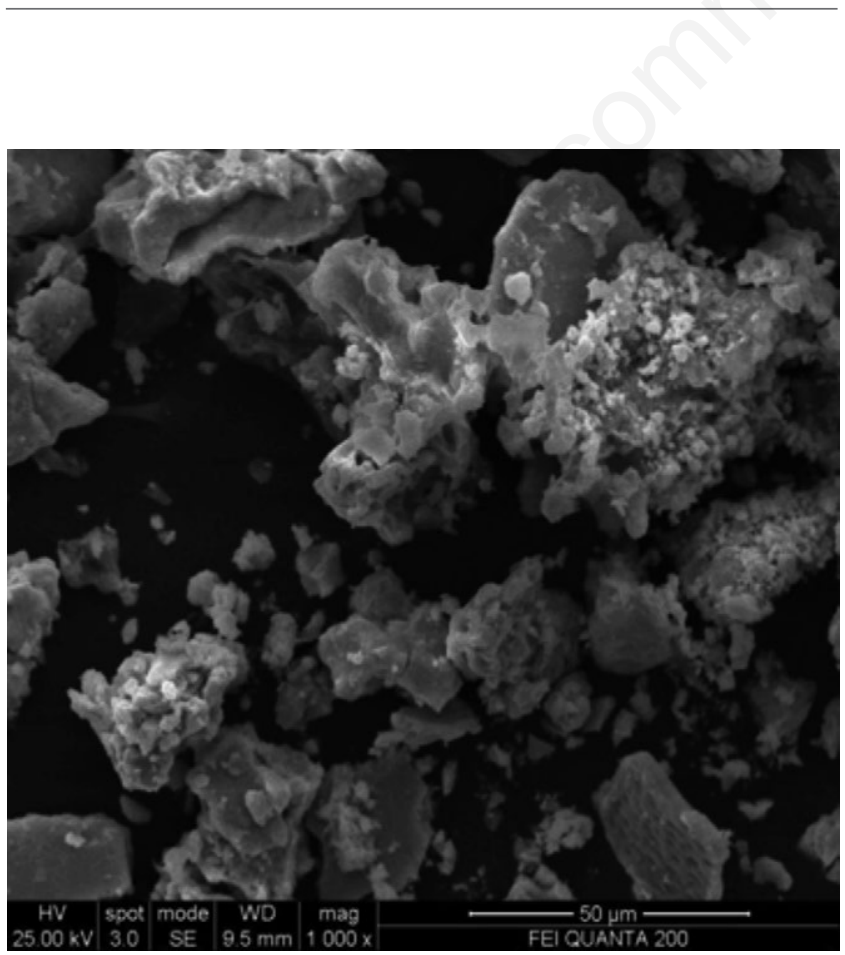

Figure 4. SEM image of silver nanoparticles synthesized using Nilgirianthus ciliatus. nanoparticles (Figure 4) obtained when exposed with Nilgirianthus ciliatus leaf extract at $90^{\circ} \mathrm{C}$ for $120 \mathrm{~min}$. The morphology of biosynthesized Ag nanoparticles studied under Scanning electron micrographs revealed that they are irregular with ovoid, spherical, rod etc. SEM results provided us an average size range in between $100 \mathrm{~nm}$ to500 $\mathrm{nm}$ with interparticle distances.

\section{Dynamic light scattering and zeta potential studies}

Dynamic Light Scattering (DLS) technique was used in this study to determine the nanoparticles size distribution (Figure 5). The monochromatic laser diffraction collected by a photomultiplier recorded the poly dispersed particles with the size ranging from $100 \mathrm{~nm}$ to $500 \mathrm{~nm}$ with a Z-Average value of $116.9 \mathrm{~nm}$. The Zetasizer's report on Zeta Potential of the biologically synthesized AgNPs revealed the stability of the metal nanoparticles in the aqueous medium (Figure 6). The Zeta Potential of the Nilgirianthus ciliatus mediated AgNPs was $-17.2 \mathrm{mV}$ confirms the repulsion among the particles and thereby increases the stability of the nanoparticles.

\section{Bio-assay}

The antibacterial activity of Silver nanoparticles formed after exposure to Nilgirianthus ciliatus leaf extract was investigated against the human pathogen, Staphylococcus aureus by disc diffusion method (Table 1). The antibacterial activity of the synthesized AgNps in $25 \mu \mathrm{L}, 50 \mu \mathrm{L}, 75 \mu \mathrm{L}$ and $100 \mu \mathrm{L}$ concentrations was quantitatively assessed on the basis of zone of inhibition. Silver nanoparticles synthesized using Nilgirianthus ciliatus leaf extract developed inhibitory zones of $0.36 \mathrm{~mm}, 0.53 \mathrm{~mm}, 0.7 \mathrm{~mm}$ and 0.9 $\mathrm{mm}$ on the live culture plates of Staphylococcus aureus when treated with $25 \mu \mathrm{L}, 50 \mu \mathrm{L}, 75 \mu \mathrm{L}$ and $100 \mu \mathrm{L}$ concentrations respectively (Figure 7).

The selected developmental stages of Aedes aegypti (I, II, III

\section{Sige Distritution by Intensity}

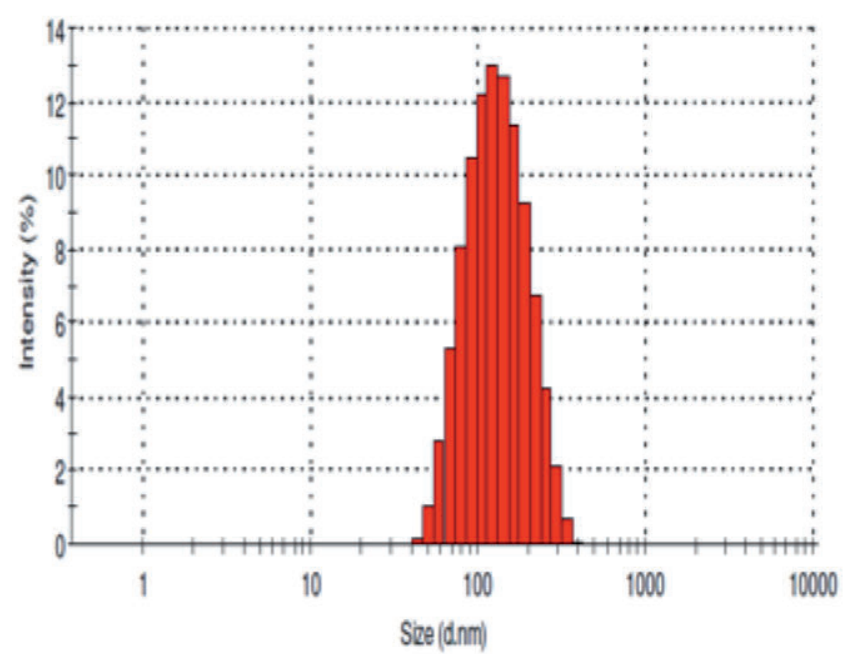

Record2:B1

Figure 5. DLS of silver nanoparticles synthesized using Nilgirianthus ciliatus. 
Table 1. Antibacterial activity of Silver nanoparticles on Staphylococcus aureus.

Concentration, g/L Zone of inhibition, $\mathrm{mm}$

\begin{tabular}{ll} 
Control & 0.0 \\
25 & 0.3 \\
\hline 50 & 0.5 \\
75 & 0.7 \\
\hline 100 & 0.9 \\
\hline
\end{tabular}

and IV instar) were not able to withstand the toxicity of biologically synthesized silver nanoparticles even at lower concentrations. $10 \mathrm{mg} / \mathrm{L}$ of AgNps were capable for killing the mosquito immatures at all developmental stages. AgNps at $1 \mathrm{mg} / \mathrm{L}$ was able kill more than $70 \%$ of the very early developmental stage of mosquitoes. $\mathrm{LC}_{50}$ for $1^{\text {st }}$ to $4^{\text {th }}$ developmental instars were $0.49,1.25,1.67$ and $4.95 \mathrm{mg} / \mathrm{L}$ respectively at $24 \mathrm{hrs}$ treatment (Table 2). The acquired chi-square values $(1.16,0.53,0.61$, and 1.31 for I, II, III, IV instars respectively) proves that the observed mortality is on a par with the expected mortality.

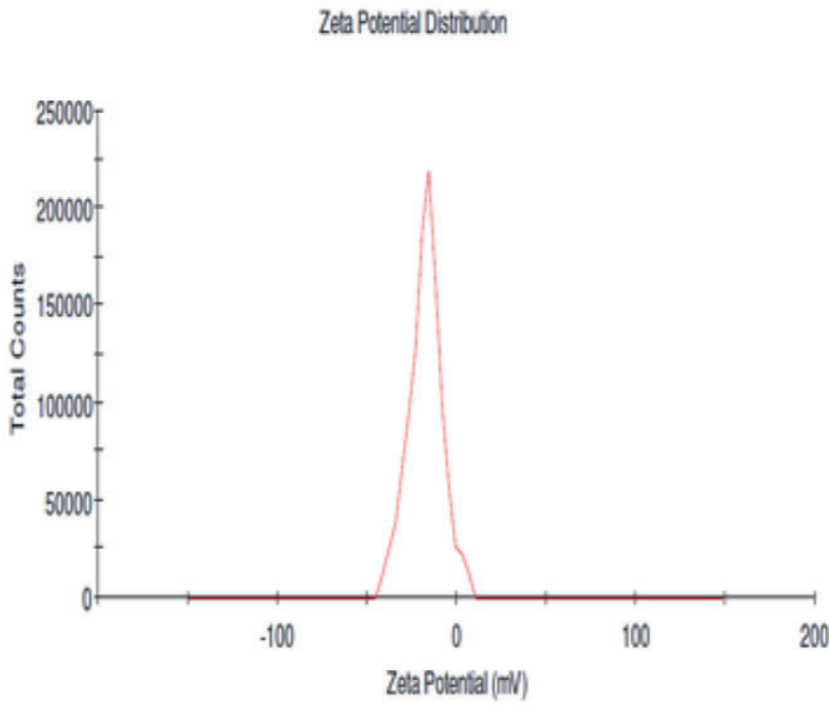

Record 5:Bzeta 1

Figure 6. Zeta potential of silver nanoparticles synthesized using Nilgirianthus ciliatus.

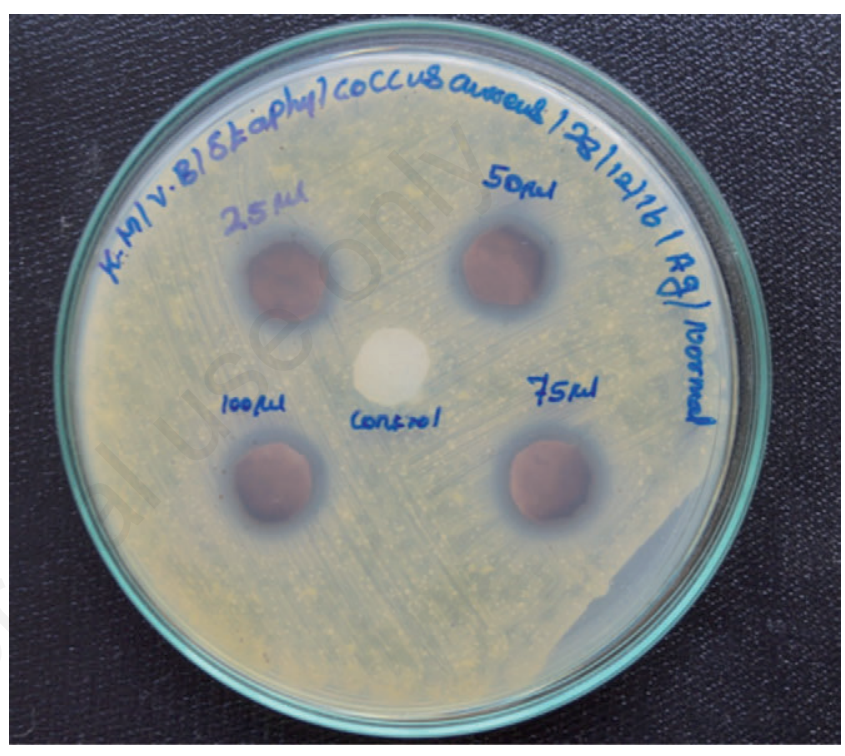

Figure 7. Antibacterial activity of Silver nanoparticles on Staphylococcus aureus.

Table 2. Efficacy of Silver nanoparticles treatment on Aedes aegypti larvae at 24 hours.

\begin{tabular}{|c|c|c|c|c|c|c|c|c|}
\hline \multirow{2}{*}{$\begin{array}{l}\text { Developmental } \\
\text { stages }\end{array}$} & \multirow{2}{*}{$\begin{array}{c}\text { Larvae } \\
\text { introduced }\end{array}$} & \multicolumn{4}{|c|}{ Mortality/concentration } & \multirow[t]{2}{*}{$\mathrm{L}_{\mathrm{c50}}$} & \multirow[t]{2}{*}{$\mathrm{L}_{\mathrm{C} 90}$} & \multirow[t]{2}{*}{$X^{2}$} \\
\hline & & Control & $1 \mathrm{mg} / \mathrm{L}$ & $5 \mathrm{mg} / \mathrm{L}$ & 10 mg/L & & & \\
\hline I instar & 100 & $0 \pm 0$ & $58.66 \pm 6.11$ & $69.33 \pm 8.32$ & $81.33 \pm 2.30$ & 0.49 & 61.63 & 1.16 \\
\hline Il instar & 100 & $0 \pm 0$ & $48.00 \pm 4.00$ & $64.00 \pm 4.00$ & $76.00 \pm 10.58$ & 1.25 & 75.83 & 0.53 \\
\hline III instar & 100 & $0 \pm 0$ & $45.33 \pm 6.11$ & $58.66 \pm 8.32$ & $70.66 \pm 2.30$ & 1.67 & 188.09 & 0.61 \\
\hline IV instar & 100 & $0 \pm 0$ & $9.33 \pm 2.30$ & $54.66 \pm 12.85$ & $68.00 \pm 10.58$ & 4.95 & 25.30 & 1.31 \\
\hline
\end{tabular}

Table 3. Efficacy of Silver nanoparticles treatment on Aedes aegypti larvae at 48 hours.

\begin{tabular}{|c|c|c|c|c|c|c|c|c|}
\hline \multirow{2}{*}{$\begin{array}{l}\text { Developmental } \\
\text { stages }\end{array}$} & \multirow{2}{*}{$\begin{array}{l}\text { Larvae } \\
\text { introduced }\end{array}$} & \multicolumn{4}{|c|}{ Mortality/concentration } & \multirow[t]{2}{*}{$\mathrm{L}_{050}$} & \multirow[t]{2}{*}{$\mathrm{L}_{\mathrm{C90}}$} & \multirow[t]{2}{*}{$X^{2}$} \\
\hline & & Control & $1 \mathrm{mg} / \mathrm{L}$ & $5 \mathrm{mg} / \mathrm{L}$ & 10 mg/L & & & \\
\hline I instar & 100 & $0 \pm 0$ & $73.33 \pm 6.11$ & $78.66 \pm 6.11$ & $85.33 \pm 2.30$ & 0.02 & 57.40 & 0.49 \\
\hline Il instar & 100 & $0 \pm 0$ & $60.00 \pm 4.00$ & $72.00 \pm 4.00$ & $81.33 \pm 8.32$ & 0.40 & 56.00 & 0.45 \\
\hline III instar & 100 & $0 \pm 0$ & $56.00 \pm 4.00$ & $68.00 \pm 8.00$ & $77.33 \pm 2.30$ & 0.58 & 105.45 & 0.37 \\
\hline IV instar & 100 & $0 \pm 0$ & $22.66 \pm 2.30$ & $64.00 \pm 10.58$ & $72.00 \pm 10.58$ & 3.28 & 27.99 & 1.16 \\
\hline
\end{tabular}


The mortality rate of Aedes aegypti was increased at $48 \mathrm{hrs}$ of treatment with Silver nanoparticles at $1 \mathrm{mg} / \mathrm{L}, 5 \mathrm{mg} / \mathrm{L}$ and 10 $\mathrm{mg} / \mathrm{L}$ concentrations (Table 3 ). Maximum mortality (100\%) was observed in all the developmental stages at treatment with 10 $\mathrm{mg} / \mathrm{L}$ concentration of silver nanoparticles. Median Lethal Concentrations were reduced to $0.02 \mathrm{mg} / \mathrm{L}, 0.40 \mathrm{mg} / \mathrm{L}, 0.58$ $\mathrm{mg} / \mathrm{L}$, and $3.28 \mathrm{mg} / \mathrm{L}$ for $1^{\text {st }}$ to $4^{\text {th }}$ instars respectively at $48 \mathrm{hrs}$ treatment.

\section{Discussion}

Development of resistances in pathogens as well as vectors for maximum available drugs and insecticides are serious threat to human health. Good numbers of synthetic chemicals are being introduced every year for the treatment of pathogens and vectors but it is most important that environmental safety and non target organisms should be taken under consideration. In concern to environment safety and resistant development novel technologies with natural products will be a best alternative to overcome the problem. Therefore, many researchers started working on plant products and nanotechnology for the management of human disease causing pathogen and disease transmitting vectors (Mickymaray et al., 2016; Madhiyazhagan et al., 2016; Shanmugapriya et al., 2016 ; Elias et al., 2017).

In this study, we focussed on development of the antibacterial and antivectorial nanoparticles using the extracts of Nilgirianthus ciliatus leaves as reducing and capping agents. The formation of Nanoparticles in the experimental setup was initially confirmed by the colour change in reaction vessels, where, yellow turned to dark brown (Logeswari et al., 2015). Further for the liquid sample was taken to UV vis spectra to verify the Surface Plasmon Resonance band coincide with that of the silver nanoparticles. We observed the resonance peak at $441 \mathrm{~nm}$, which was a specific character of silver nanoparticles. The present result matches with the results of recent researches by (Gudikandula \& Maringanti, 2016), (Ali et al., 2016) and many others.

The size and shape of the Nilgirianthus ciliatus mediated silver nanoparticles were similar to that of many reports of research done throughout the world (Sharma et al., 2017; Basavegowda et al., 2014). Reaction time plays a major role in the size and shape of the nanoparticles Verma et al. (2016) in our study we observed 120 min to be the optimum reaction time for nanoparticles in a range between 50 to $150 \mathrm{~nm}$. Zeta Potential record $(-17.2 \mathrm{mV})$ of the biosynthesized AgNPs using Nilgirianthus ciliatus in this study was up to mark proving the stability of the particles in the medium. Earlier reports on silver and other metal nanoparticles were in support to the Zeta Potential record of this study (Premasudha et al., 2016; Trinh et al., 2015).

The secondary metabolites of Nilgirianthus ciliatus leaves are the responsible agents for reducing, capping and stabilizing the metal nanoparticles. FTIR spectral bands confirmed the presence of hydroxyl group, carbonyl compounds, and methyl groups of polyphenols, flavonoids, terpenoids, aldehydes and ketones of Nilgirianthus ciliatus surrounding the silver nanoparticles or the reductants which disappeared later. Preceding results of many studies showed identical stretching vibrations confirming the presence of above mentioned organic compounds surrounding the metal nanoparticles (Trinh et al., 2015; Subbaiya et al., 2014). Further, XRD spectrum showed that the structure corresponds to face-centered cubic crystal of Silver. Pure Ag crystallite was obtained with the absence of unassigned peaks, weak peaks, oxide of Ag and incomplete peaks (Ghodsieh et al., 2017).
Silver is known for its antimicrobial activity from very ancient time. It has been an effective agent in wound healing, curing infections, reducing bacterial burden, post-operative incision dressings, blood and urinary catheter designs, endotracheal tubes, orthopedic devices, vascular prostheses, and the sewing ring of prosthetic heart valves (Politano et al., 2013).In this study, Silver nanoparticles synthesized using Nilgirianthus ciliatus leaf extract was tested for its efficacy in controlling the bacterial pathogen, Staphylococcus aureus. Silver nanoparticles were highly energetic in this case to control the bacterial pathogen as it required very low concentration for destroying maximum possible cells. Silver nanoparticles have a multiple mechanism of action on microbes reported since last two decades. Silver nanoparticles adheres to the bacterial cell wall and taking advantage of its size it penetrates the cell causing structural changes in the cell affecting permeability and finally leading to death of the cell(Sondi and Sondi, 2004). They form free radicals that damage the membrane and also interact with thiol groups in enzymes and phosphorus-containing bases, thus interact with DNA and prevent cell division leading to cell death Morones et al. (2005); Li et al. (2013) reported changes in protein, hypoxanthine, adenosine, and guanosine bands suggesting that Ag NPs have a significant impact on the protein and metabolic processes of purine.

Results obtained from the Larvicidal activity of silver nanoparticles mediated by Nilgirianthus ciliatusleaf extract shows that the nano silver will be a best alternative for synthetic larval control agents of Aedes aegypti. Silver Nanoparticles were much effective even at the lower concentration and for the late developmental stages of Aedes aegypti, which was failed by many synthetic chemicals. Effect of silver nanoparticles on Aedes aegypti in this study was greater that the effect reported earlier on Culex quinquefasciatus and Anopheles stephensi Chandrashekhar et al. (2012); Udaiyan et al. (2015) may be due to size of the particle or the biomolecules surrounding the nano silver reaching the target efficiently. Mechanism involved might be the penetration of Ag nanoparticles through the larval membrane targeting the phospholipids bilayer arresting the molting process which was seen rare in the treated larvae (Rawani, 2017; Murugan et al., 2015; Arjunan et al., 2012). Whereas, earlier Morsy et al. (2001) reported that Ag nanoparticles binds to the sulfur containing proteins and phosphorous containing DNA leads to inhibition of protein and DNA synthesis leading to decreased permeability and imbalanced proton motive force causing morphological deformation and death.

\section{Conclusions}

Silver nanoparticles synthesized using plant products are costeffective environment friendly, target specific molecules and promising agents against the pathogenic microbes and disease transmitting vectors. From this study we conclude that the Nilgirianthus ciliatus leaf is hub of secondary metabolites that has the capability to act as reducing and capping agent in formation of silver nanoparticles. Studies needed to identify the exact molecules in Nilgirianthus ciliatus responsible for reducing as well as capping the silver ions and nanoparticles respectively to reduce the utilization of bio-resources. Further research on monodispersed nanoparticles can increase the biotoxicity against microbial pathogens and mosquito immature making it more suitable for commercialization. Present findings would prompt future research on nanotechnology in all aspects of life sciences. 


\section{References}

ABBOTT W.S., 1925 - A method of computing the effectiveness of insecticides. - J. Eco. Ento. 18: 265-7.

ADIBHESAMI M., AHMADI M., ABBAS FARSHID A., SARRAFZADEH-REZAEI F., DALIR-NAGHADEH B., 2017 Effects of silver nanoparticles on Staphylococcus aureus contaminated open wounds healing in mice: An experimental study. - Vet. Res. Forum. 8: 23-8.

ALI A.S., ZANZINGER Z., DEBOSE D., STEPHENS B., 2016 - Open Source Building Science Sensors (OSBSS): A lowcost Arduino-based platform for long-term indoor environmental data collection. - Build. Environ. 100: 114-26.

ARJUNAN N.K., MURUGAN K., REJEETH C., MADHIYAZHAGAN P., BARNARD D.R., 2012 - Green synthesis of silver nanoparticles for the control of mosquito vectors of malaria, filariasis, and dengue. - Vector. Borne Zoonotic Dis. 12: $262-8$.

AZMI W., SANI R.K., BANERJEE U.C., 1998 - Biodegradation of triphenyl methane dyes. - Enzyme. Microb Tech. 22: 185-191.

BASAVEGOWDA N., IDHAYADHULLA A., LEE Y.R., 2014 Tyrosinase inhibitory activity of silver nanoparticles treated with Hoveniadulcis fruit extract: an in vitro study.- Mater. Lett. 129: 28-30.

BENELLI G., GOVINDARAJAN M., SENTHILMURUGAN S., VIJAYAN P., KADAIKUNNAN S., ALHARBI N.S., KHALED J.M., 2017 - Fabrication of highly effective mosquito nanolarvicides using an Asian plant of ethno-pharmacological interest, Priyangu (Aglaia elaeagnoidea): toxicity on non-target mosquito natural enemies.- Environ Sci Pollut Res. https://doi.org/10.1007/s11356-017-8898-4.

CHANDE C.A., SHRIKHANDE S.N., JAIN D.L., KAPALE S., CHAUDHARY H., POWAR R.M., 2009 - Prevalence of methicillin-resistant Staphylococcus aureus nasopharyngeal carriage in children from urban community at Nagpur. Indian J. Public Health 53: 196-8.

CHANDRASHEKHAR D., PATIL SATISH V., PATIL HEMANT P., BORASE BIPINCHANDRA K., SALUNKE RAHUL B., SALUNKHE, 2012 - Larvicidal activity of silver nanoparticles synthesized using Plumeria rubra plant latex against Aedes aegypti and Anopheles stephensi. - Parasitol. Res. 110: 1815-22.

CUNY C., FRIEDRICH A., KOZYTSKA S., LAYER F., NUBEL U., OHLSEN K., STROMMENGER B., WALTER B., WIELER L., WITTE W., 2010 - Emergence of methicillinresistant Staphylococcus aureus (MRSA) in different animal species.- Int. J. Med Microbiol. 300: 109-17.

DIAO W.R., HU Q.P., FENG S.S., LI W.Q., XU J.G., 2013 Chemical composition and antibacterial activity of the essential oil from green huajiao (Zanthoxylum schinifolium) against selected food borne pathogens.- J. Agric. Food Chem. 61: 6044-9.

EDWARDS A.M.M., MASSEY R.C.C., CLARKE S.R.R., 2012 - Molecular mechanisms of Staphylococcus aureus nasopharyngeal colonization. - Mol. Oral Microbiol. 27:1-10.

ELIAS E., ELEMIKE DAMIAN C., ONWUDIWE ANTHONY C., EKENNIA CHRISTOPHER U., SOND RICHARD C., EHIRI. 2017 - Green Synthesis of Ag/Ag2O Nanoparticles Using Aqueous Leaf Extract of Eupatorium odoratum and Its Antimicrobial and Mosquito Larvicidal Activities. Molecules 22: 1-15.
GAMBARRA W.P.T., MARTINS W.F.S., LUCENA FILHO M.L.D., ALBUQUERQUE I.M.C.D., APOLINARIO O.K.D.S., BESERRA E.B., 2013 - Spatial distribution and esterase activity in populations of Aedes (Stegomyia) aegypti (Linnaeus) (Diptera: Culicidae) resistant to temephos.- Rev. Soc. Bras. Med. Trop. 46: 178-84.

GARCEZ W.S., GARCEZ F.R., SILVA L.M.G.E., SARMENTO U.C., 2013 - Substancias de origem vegetal com atividade larvicida contra Aedes aegypti. - Rev. Virtual Quim. 5: 363-93.

GHODSIEH B., MARYAM M.T., MOHMMAD H.N., 2017 Green synthesis of silver nanoparticles using aqueous extract of saffron (Crocus sativus L.) wastages and its antibacterial activity against six bacteria.- Asian. Pac J. Trop Biomed. 7:227-33

GHOSH A., CHOWDHURY N., CHANDRA G., 2012 - Plant extracts as potential mosquito larvicides. Indian.- J. Med Res. 135:581-98.

GUDIKANDULA K., MARINGANTI S.C., 2016 - Synthesis of silver nanoparticles by chemical and biological methods and their antimicrobial properties.- J. Exp. Nanosci 11: 714-21.

HA S.J., FOWLER V.G., 2013 - Is it time to replace vancomycin in the treatment of methicillin-resistant Staphylococcus aureus infections? - Clin. Infect. Dis. 56: 1779-88.

HAFEEZ S., AMIN M., MUNIR B.A., 2017 - Spatial mapping of temporal risk to improve prevention measures: A case study of dengue epidemic in Lahore. Spatiotemporal Epidemiol. 21: 77-85.

HAMED S., EMARA M., SHAWKY R.M., EL-DOMANY R.A., YOUSSEF T., 2017 - Silver nanoparticles: Antimicrobial activity, cytotoxicity, and synergism with $\mathrm{N}$-acetyl cysteine. J. Basic Microbiol. 57: 659-68.

KUMAR V.A., AMMANI K., JOBINA R., SUBHASWARAJ.P., SIDDHARDHA B., 2017 - Photo-induced and phytomediated synthesis of silver nanoparticles using Derris trifoliata leaf extract and its larvicidal activity against Aedes aegypti.J. Photochem Photobiol B. 171: 1-8.

LI J., RONG K., ZHAO H., LI F., LU Z., CHEN R., 2013 Highly selective antibacterial activities of silver nanoparticles against Bacillus subtilis. - J. Nano Sci Nanotechnol 13: 6806-13.

LI M.I., WONG P.S., NG L.C., TAN C.H., 2012 - Oral susceptibility of Singapore Aedes (Stegomyia) aegypti (Linnaeus) to Zika virus.- PLoS. Negl. Trop. Dis. 6: 1-6.

LOGESWARI P., SILAMBARASAN S., ABRAHAM J., 2015 Synthesis of silver nanoparticles using plants extract and analysis of their antimicrobial property. - J. Saudi Chem. Soc. 19: 311-7.

MADHIYAZHAGAN P., AMERASAN D., NATARAJ T., MURUGAN K., PANNEERSELVAM C., NICOLETTI M., BENELLI G., 2016 - Myco-synthesis of silver nanoparticles using Metarhizium anisopliae against the rural malaria vector Anopheles culicifacies Giles (Diptera: Culicidae). - J. Pest Sci. 89: 249-56.

MARIA C.F., KRISHNAN S., 2016 - Phytochemical Analysis of Strobilanthes blume species from Northern Western Ghats of India.- Int. J. Curr. Pharm. Res. 8: 108-11.

MATHEW J.J., VAZHACHARICKAL P.J., SAJESHKUMAR N.K., JESMI SUNIL 2015 - Larvicidal Activity of Gliricidia sepium leaf extracts on Mosquito larvae and it's Lethal Effect on non-targeted Organisms. - CIB Tech J Biotechnol. 4: 13-9.

MICKYMARAY S., SALEH A., ABOODY M., KUMAR RATH P., ANNAMALAI P., NOORUDDIN T., 2016 - Screening 
and antibacterial efficacy of selected Indian medicinal plants.- Asian Pac. J. Trop Biomed. 6: 185-91.

MORONES J.R., ELECHIGUERRA J.L., CAMACHO A., HOLT K., KOURI J.B., RAMIREZ J.T., 2005 - The bactericidal effect of silver nanoparticles. - Nanotechnol. 16: 46-53.

MORSY T.A., MOHAMMAD A.A., KAMELIA A.M., 2001Control of Musca domestica third instar larvae by the latex of Calotropis procera (Family: Asclepiadaceae). - J. Egypt Soc. Parasitol. 31:107-10.

MURUGAN K., SAMIDOSS C.M., PANNEERSELVAM C., HIGUCHI A., RONI M., SURESH U., CHANDRAMOHAN B., SUBRAMANIAM J., MADHIYAZHAGAN P., DINESH D., RAJAGANESH R., ALARFAJ A.A., NICOLETTI M., KUMAR S., WEI H., CANALE A., MEHLHORN H., BENELLI G., 2015 - Seaweed-synthesized silver nanoparticles: an eco-friendly tool in the fight against Plasmodium falciparum and its vector Anopheles stephensi. - Parasitol. Res. 114: 4087-97.

MUTHUKUMARAN U., GOVINDARAJAN M., RAJESWARY M., 2015 - Green synthesis of silver nanoparticles from Cassiarox burghii: a most potent power for mosquito control. - Parasitol Res. 114: 4385-95.

NARESHKUMAR A., JEYALALITHA T., MURUGAN K., MADHIYAZHAGAN P., 2013 - Bioefficacy of plant-mediated gold nanoparticles and Anthocepholus cadamba on filarial vector, Culex quinquefasciatus (Insecta: Diptera: Culicidae).Parasitol. Res. 112: 1053-63.

NEETHU V., SHERON J., SHEEBA JASMINE T.S., DIVYA G.S., 2014 - Study of Phytochemical and antimicrobial potential of the leaves of Nilgirianthus ciliatus Linn. - Int. J. Appl. Biol. Pharm. 5: 150-2.

PEREIRA A.I.S., PEREIRA A.D.G.S., SOBRINHO L., PALMA O., CANTANHEDE E.D.K.P., SIQUEIRA L.F.S., 2014 Antimicrobial activity in fighting mosquito larvae Aedes aegypti: Homogenization of essential oils of linalool and eugenol. - Educ. Qu1m. 25: 446-9.

PERSSON Y., NYMAN A.K., GRONLUND-ANDERSSON U., 2011 - Etiology and antimicrobial susceptibility of udder pathogens from cases of subclinical mastitis in dairy cows in Sweden. - Acta. Vet. Scand. 8: 36-53.

POLITANO A., FORMOSO V., CHIARELLO G., 2013 Interplay between single-particle and plasmonic excitations in the electronic response of thin Ag films. - J. Phys. Condens. Matter. 25-30.

PRADO G.P., MACIE J.S., LEITE G.R., SOUZA M.A.A., 2017 - Influence of shading and pedestrian traffic on the preference of Aedes (Stegomyia) aegypti (Diptera: Culicidae) for oviposition microenvironments. - J. Vector Ecol. 42: 155-60.

PREMASUDHA P., VENKATARAMANA M., ABIRAMI M., VANATHI P., KRISHNA K., RAJENDRAN R., 2015 Biological synthesis and characterization of silver nanoparticles using Eclipta alba leaf extract and evaluation of its cytotoxic and antimicrobial potential.- Bull. Mater Sci. 38: 965-73.

PRIYA R.S., GEETHA D., RAMESH P.S., 2016 - Antioxidant activity of chemically synthesized AgNPs and biosynthesized Pongamia pinnata leaf extract mediated AgNPs - A comparative study. - Ecotoxicol. Environ Saf. 134: 308-18.

RAMESHKUMAR R., LARGIA M.J.V., SATISH L., SHILPHA J., RAMESH M., 2015 - In vitro mass propagation and conservation of Nilgirianthus ciliatus through nodal explants. A globally endangered high trade medicinal plant of Western Ghats.- Plant Bio. Syst. Plant Biosystems. 151: 204-11.
RANI K.U., AMIRTHAM D., SELVAM N.T., 2013 Hepatoprotective activity of Nilgirianthus ciliatus (Nees) bremek in paracetamol induced toxicity in Wistar albino rats.- J. Intern. Med. 1:26-30.

RAWANI A., 2017 - Mosquito larvicidal activity of green silver nanoparticle synthesized from extract of bud of Polianthus tuberosa L. - Int. J Nanotechnol. Appl. 11:17-28.

ROBERTS N., 1998 - The Holocene: An Environmental History, Oxford, Blackwell.

SANTHOSH S.B., RAGAVENDRAN C., NATARAJAN D., 2015 - Spectral and HRTEM analyses of Annona muricata leaf extract mediated silver nanoparticles and its Larvicidal efficacy against three mosquito vectors Anopheles stephensi, Culex quinquefasciatus, and Aedes aegypti.- J. Photochem. Photobiol. 153: 184-90.

SHAK J.R., VIDA J.E., KLUGMAN K.P., 2013 - Influence of bacterial interactions on pneumococcal colonization of the nasopharynx. - Trends Microbiol. 21: 129-35.

SHANMUGAPRIYA S., SENTHURSELVI R., BHUVANESWARI K.A., 2016 - Study comparing the anorectic activity of hot and cold aqueous extracts of Dolichos biflorus Linn. Seeds in freely feeding rats.- Int. J Pharm Sci. 8: 336-9.

SHARMA P., PANT S., RAI S., BALAYADAV R., DAVE V., 2017 - Green Synthesis of Silver Nanoparticle Capped with Allium cepa and their Catalytic Reduction of Textile Dyes: An Ecofriendly Approach. - J. Polym. Environ. 1-9.

SINGLA N., CHAUDHARY P., THAKUR M., CHANDER J., 2016 - Dengue: An Analysis of Epidemiological Pattern over a six year period. - J. Clin. Diagn. Res. 10: 12-4.

SONDI I., SONDI B.S., 2004 - Silver nanoparticles as antimicrobial agent: a case study on $E$. coli as a model for gram-negative bacteria. - J Colloid Interface Sci. 275: 177-82.

STRODE C., DE MELO-SANTOS M., MAGALHAES T., ARAUJO A., AYRES C., 2012 - Expression profile of genes during resistance reversal in a temephos selected strain of the dengue vector, Aedes aegypti. - PLoS ONE 7: 39-439.

SUBBAIYA R., SHIYAMALA M., REVATHI K., PUSHPALATHA R., MASILAMANI S.M., 2014 - Biological synthesis of silver nanoparticles from Nerium oleander and its antibacterial and antioxidant property.- Int. J. Curr. Microbiol. Appl. Sci. 3: 83-7.

SUGANYA G., KARTHI S., MUTHUGOUNDER S., SHIVAKUMAR, 2014 - Larvicidal potential of silver nanoparticles synthesized from Leucas aspera leaf extracts against dengue vector Aedes aegypti. - Parasitol. Res. 113: 1673-9.

TRINH T., BRANCH A., HAMBLY A.C., CARVAJA G., COLEMAN H.M., STUETZ R.M., DREWES J.E., LE-CLECH P., KHAN S.J., 2015 - Hazardous events in membrane bioreactors - Part 1: Impacts on key operational and bulk water quality parameters. - J. Memb. Sci. 497: 494-503.

UDAIYAN M., MARIMUTHU MOHAN R., HOTI S.L., 2015 Synthesis and characterization of silver nanoparticles using Gmelina asiatica leaf extract against filariasis, dengue, and malaria vector mosquitoes. - Parasitol. Res. 114: 1817-27.

VASANTHA P., SENTHILNATHAN S., THANIGAIVEL A., EDWIN E., PONSANKAR A., SELIN-RANI S., PRADEEPA V., SAKTHIBHAGAVATHY M., KALAIVANI K., HUNTER W.B., DURAIPANDIYAN V., AL-DHABI N.A., 2016 - Developmental response of Spodoptera litura Fab. To treatments of crude volatile oil from Piper betle L. 
and evaluation of toxicity to earthworm, Eudrilus eugeniae Kinb. - Chemosphere 155: 336-47.

VERMA A., MEHATA S.M., 2016 - Controllable synthesis of silver nanoparticles using Neem leaves and their antimicrobial activity.- J. Radiat Res Appl Sci. 9: 109-15.

WHO, 2005 - Guidelines for laboratory and field testing of mosquito larvicides. Communicable disease control, prevention and eradication, WHO pesticide evaluation scheme. - WHO Geneva.

ZECCONI A., CESARIS L., LIANDRIS E., DAPRA V., PICCININI R., 2006 - Role of several Staphylococcus aureus virulence factors on the inflammatory response in bovine mammary gland. - Microb. Pathog. 40: 177-83. 